\title{
Managing Diversity in Liberal Arts College Libraries
}

\section{Mark D. Winston and Haipeng Li}

\begin{abstract}
Although fostering diversity has been identified as a priority in librarianship, the evidence suggests that the majority of the programs related to diversity in academic libraries have been implemented in large, research university libraries. In this study of the liberal arts college libraries in the United States, data were gathered with regard to programs related to diversity awareness, staffing, information services, and library collections. Although the level of diversity-related activities in liberal arts college libraries has not been overwhelming, the evidence suggests that activities and programs related to diversity have been undertaken in some instances. In addition, the support of college administrators appears to be particularly important in encouraging these activities.
\end{abstract}

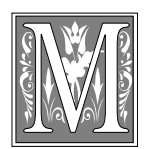

any in the academic library profession are well aware of the importance of increasing diversity in the workplace. Academic libraries throughout the country are sponsoring diversity initiatives and programs that are designed specifically to achieve that end. A review of the library literature shows that a great deal of scholarship has been done on the diversity programs implemented in academic libraries. Generally, these programs focus on recruitment and retention of members of underrepresented groups, increasing diversity awareness in the workplace, building multicultural collections, and designing and providing library services for users from diverse cultural backgrounds. With regard to recruitment, an increasing number of residency programs designed to enhance the recruitment of minority librarians have been implemented in the past ten or fifteen years at institutions including Cornell University, Iowa State University, Ohio State University, the University of Michigan, and Yale University, among others. ${ }^{1}$ These programs are designed to provide recent graduates of color from library and information science (LIS) programs with entry-level positions in order to equip them with the necessary experience to advance professionally in academic and research libraries. Based on the research conducted by Julie Brewer, residency programs seem to be effective tools for attracting minorities and other new library professionals, and they benefit both the individuals hired for residency positions and the academic institutions that host these programs. ${ }^{2}$

Also noteworthy is another minority recruitment effort, the Peer Information Counseling Programs, designed to attract

Mark D. Winston is an Assistant Professor in the School of Communication, Information and Library Studies at Rutgers University; e-mail: mwinston@scils.rutgers.edu. Haipeng Li is a Reference Librarian in Oberlin College Library; e-mail: haipeng.li@oberlin.edu. 
students of color to the library profession. These programs are geared toward undergraduate students of color who are hired to provide basic reference services for their peers and to perform related functions in order to ensure the best use of the library and to provide role models for other students of color. As such, these programs provide the opportunity to expose minority undergraduate students to reference service, an aspect of academic and research library information services that usually is not open to them, and thus to provide a mechanism for encouraging their interest in the profession. Research conducted by Mark Winston and Karen Downing shows that five institutions currently host Peer Information Counseling Programs, including the Cleveland State University, the University of Michigan, the University of Arizona, Valdosta State University, and the University of Oregon. ${ }^{3}$

\section{Although efforts to promote diver- sity are taking place, a review of the literature indicates that diversity initiatives and programs in small liberal arts college libraries are basically nonexistent.}

In relation to the issue of awareness, diversity training and cultural sensitivity training have been considered in the literature with regard to efforts to support goals including those related to awareness and services to diverse student populations. In addition, a number of libraries have undertaken diversity climate surveys. For example, David Day, a psychology professor, facilitated a diversity climate survey within the Pennsylvania State University Library system. In considering issues such as demographic composition and changes in staff, how diversity is defined within the organization, and administrative support for diversity, he was able to show how such a survey can be a useful tool in uncovering hidden problems among staff members from different backgrounds. In addition, he showed that the results of a climate assessment can be used to lead to future changes and improvements. $^{4}$

Although efforts to promote diversity are taking place, a review of the literature indicates that diversity initiatives and programs in small liberal arts college libraries are basically nonexistent. The majority of diversity programs and initiatives have been undertaken at large research university libraries. Indeed, nearly all the academic libraries that currently host minority residency programs are research institutions with extensive graduate programs. ${ }^{5}$ For example, the research library system at the Ohio State University, with an enrollment of more than 54,000 students, of which more than 10,000 are graduate students, has hosted a minority residency program for several years. ${ }^{6}$ Another example is the University of Michigan Library, which was one of the first institutions in the country to undertake diversity initiatives and programs in areas such as minority recruitment and retention and bibliographic instruction. ${ }^{7}$ In "Diversity in the Library: What Could Happen at the Institutional Level," Haipeng Li discussed the need for, and relative lack of, diversity programs and initiatives in liberal arts college libraries and the efforts at Oberlin College to implement diversity programs in a liberal arts college library environment. ${ }^{8}$

All academic libraries may face many of the same challenges and have similar opportunities. Certainly, small college libraries are being forced to cope with new demands and technological developments at the same time that large institutions are struggling to adapt. ${ }^{9}$ However, according to Robert D. Stueart, “Today's libraries in liberal arts institutions are by their very nature in a state of overload, both in terms of information and in demand from the environment." ${ }^{10}$ Generally, large academic research libraries possess financial or personnel resources that small college libraries lack. ${ }^{11}$ Because the role of the academic library in liberal arts institutions remains central to their instructional mission and teaching functions, the challenge for the liberal arts 
college libraries is to build collections and provide services conducive to the changing needs of their institutions, most of which are not publicly funded. Moreover, the need exists to deal with issues related to diversity in the unique small college library environment.

With limited resources and constrained budgets, increasing expectations and pressures, the college library must find ways to address diversity issues and reflect these changes in collections, services, and staffing. Thus, this article presents the results of a research study related to diversity in liberal arts college libraries in the United States. Its primary focus is to identify diversity-related programs, activities, and priorities in U.S. liberal arts colleges, with a special emphasis on the following areas: staffing, workplace environment, collections, and services.

\section{Methodology}

To gather data for this study, survey methodology was used, with a direct mailing of questionnaires to liberal arts college library directors. The survey instrument used in this study was adapted from one used in an earlier study of research libraries and was designed to address issues of diversity awareness, staffing, information services, and collections.

In 1997, the Association of Research Libraries (ARL) conducted a study of academic and research university libraries called Affirmative Action in ARL Libraries. ${ }^{12}$ The ARL study focused on issues of staffing, including recruitment, statistical measures of staff composition, and retention, and supplemented ARL SPEC Kit \#163, Affirmative Action Policies and Practices in ARL Libraries, compiled in 1990. The study was based on feedback to a survey sent to one hundred and twenty ARL member libraries, of which a hundred and eight were academic libraries. Results of the survey indicated that in many instances, libraries had not nominally distinguished between an affirmative action policy and a diversity program. The results of the ARL study also indicated that, with regard to issues of recruitment and retention, most of the libraries surveyed (65\%) "regularly collect affirmative action statistics." ${ }^{13}$ Nearly all of the research library respondents (95\%) reported that there is a campus affirmative action officer in their institution. ${ }^{14}$ In terms of recruitment, twentyeight of the forty-three respondents reported that they try to identify candidates from protected classes through targeted mailings and invitation letters when positions are open, compared to twelve institutions that reported no specific efforts to ensure that members of protected groups are included in candidate pools. ${ }^{15}$

Although the survey results showed an increase in awareness of the need for commitment to future development of affirmative action policies and programs, the researchers conclude that libraries may go through a transformation process of "targeting selected groups that have been legally excluded from social, educational, and professional opportunities, towards diversity, which celebrates the unique and valuable contributions of every member of society."16

Upon obtaining permission from ARL to use the questionnaire for this study, the authors modified it for the population of liberal arts college libraries and expanded it to include more discussion of diversity awareness and library and information services and library collection development and assessment. Specifically, participants were asked about the existence of a library diversity committee and a library or college diversity or affirmative action officer, as well as about training for library search committees with regard to diversity issues. General approaches to increasing awareness of diversity, such as diversity workshops and climate surveys, were considered, as were staffing issues related to documenting minority representation in staff composition, recruitment and retention strategies, library services for diverse student populations, and assessment and development activities designed to evaluate and diversify collections. 


\begin{tabular}{|c|c|c|}
\hline \multicolumn{3}{|c|}{$\begin{array}{c}\text { TABLE } 1 \\
\text { Efforts to Attract a Diverse } \\
\text { Pool of Applicants } \\
\end{array}$} \\
\hline & $\begin{array}{c}\text { No. of } \\
\text { Libraries }\end{array}$ & $\begin{array}{l}\% \text { of } \\
\text { Total } \\
\end{array}$ \\
\hline Professional positions & 96 & 86.5 \\
\hline Support staff positions & 79 & 71.2 \\
\hline Student employee position & ns 62 & 55.9 \\
\hline
\end{tabular}

replied, reflecting an overall rate of return of 72 percent. Three respondents returned the questionnaires with notes but did not complete the questionnaires, or replied via e-mail. Specifically, 112 usable questionnaires were returned, reflecting a rate of return of 70 percent.

The findings of this study and the future research that is

To identify members of the target population for this study, the Carnegie Foundation for the Advancement of Teaching classifications were used to identify all of the institutions designated as Baccalaureate (Liberal Arts) Colleges I. ${ }^{17}$ One hundred sixty-six institutions were so identified. Because several of the potential participants are consortial institutions and share the same directors, the number of mailings was reduced to 159 single institutions. The American Library Directory was used to identify the current library directors and the mailing addresses of the libraries at these colleges; and then questionnaires, with cover letters and stamped, self-addressed return envelopes, were mailed to each of the directors in December 1998. A follow-up mailing was sent in February 1999 to those who did not respond initially. In total, 115 institutions needed in this area reflect an analysis of data based on responses from liberal arts college library directors, who were asked about staffing, diversity awareness, services, and collections.

\section{Staffing, Recruitment, and Hiring}

It is interesting to note the types of recruitment activities that are undertaken to fill positions in liberal arts college libraries. As table 1 shows, more than 85 percent of the respondents have made efforts to attract a diverse pool of candidates for open professional positions. Fewer have undertaken such efforts with regard to support staff positions $(71.2 \%)$ and student employee positions (55.9\%).

As seen in table 2, the most widely used approaches in attempting to identify minority candidates for open professional positions include posting job an-

\begin{tabular}{|lcc|}
\hline \multicolumn{3}{c|}{ TABLE 2 } \\
Recruitment Activities \\
\hline \hline Activity & $\begin{array}{c}\text { No. of } \\
\text { Libraries }\end{array}$ & $\begin{array}{c}\text { \% of } \\
\text { Total }\end{array}$ \\
\hline Position postings in national publications & 84 & 75.7 \\
Mailing postings to LIS program deans & 66 & 59.5 \\
Position postings in minority publications & 47 & 42.3 \\
Position postings on minority listservs & 45 & 40.5 \\
Targeted mailings to potential applicants & 34 & 30.6 \\
Contacting specific minority organizations & 27 & 24.3 \\
Establishing contacts at professional/scholarly & & 21.6 \\
conferences & 24 & 17.1 \\
Seeking recommendations from prominent & & 8.1 \\
members of underrepresented populations & 19 & 5.4 \\
Using directories of ethnic professionals & 9 & \\
Maintaining a database of potential candidates & 6 & \\
\hline
\end{tabular}




\begin{tabular}{|lcr|}
\hline \multicolumn{3}{c|}{$\begin{array}{c}\text { TABLE 3 } \\
\text { Retention Efforts }\end{array}$} \\
\hline \hline & $\begin{array}{c}\text { No. of } \\
\text { Libraries }\end{array}$ & $\begin{array}{c}\text { \% of } \\
\text { Total }\end{array}$ \\
\hline Connecting new minority hires with others on & 15 & 13.5 \\
campus/in community & 6 & 5.4 \\
Sensitivity training for other library staff & 4 & 3.6 \\
Mentoring program for minority librarians & & 2.7 \\
Obtaining/using feedback from minority & 3 & 1.8 \\
librarians who leave & 2 & 51.4 \\
Salary adjustments/counteroffers for & 57 & 36.9 \\
minority librarians & 41 & \\
No program & & \\
No minority librarians & & \\
\hline
\end{tabular}

nouncements in national publications $(75.7 \%)$, mailing job announcements to deans of library schools (59.5\%), and posting job announcements in minority publications $(42.3 \%)$ or on listservs with substantial numbers of minority participants (40.5\%).

In terms of implementing target-of-opportunity programs for underrepresented populations, only 6.3 percent of the libraries have used such programs often in the past. In addition, 10.8 percent have rarely used them, compared to 73 percent that have never used them, as reported by the directors. With regard to other related issues of recruitment and hiring, the directors were asked whether library search committees are trained in issues of diversity. Slightly less than half (45\%) indicated that such training is provided. Of those library search committees that do receive training in issues of diversity, nearly twothirds reported that it is the college personnel or affirmative action officer who provides the training. In addition, library personnel or affirmative action officers provide this training for eight of the institutions $(16.3 \%$ of those that provide such training). Library and campus personnel officers work together to provide the training in four of the libraries. Other responses indicated that trainers include the dean of the college, the library director, the human resources office, and a campus committee, as well as training in the form of instructions from the institution, each of these instances occurring in one institution.

Statistics on the demographic composition of the library staff are compiled in 43.2 percent of the responding institutions. In general, such statistics are compiled by either an administrative officer in the library such as the director or assistant director $(46.8 \%$ of those that compile them), the campus affirmative action officer $(40.4 \%)$, both of these individuals $(10.6 \%)$, or the library's human resources or personnel officer $(2.1 \%)$.

In addition to considering the issue of recruitment, the respondents were asked about their efforts related to the retention of minority librarians. It should be noted that more than half of the respondents $(51.4 \%)$ indicated that they undertake no specific efforts in this regard (table 3). In fact, more than a third (36.9\%) employ no minority librarians at present. The most widely used approach relates to connecting newly hired minority librarians with other minority faculty and staff on the campus, as reported by 13.5 percent of the directors. Approximately five percent reported the use of sensitivity training for librarians and staff to assist with retention. However, less than four percent indicated the use of each of a number of other approaches, such as mentoring programs for minority librarians, salary adjustments or counteroffers for minority 


\begin{tabular}{|lcr|}
\hline \multicolumn{3}{c|}{ TABLE 4 } \\
Evaluation of Minority Representation \\
\hline \hline Method of Evaluation & $\begin{array}{c}\text { No. of } \\
\text { Libraries }\end{array}$ & $\begin{array}{c}\text { \% of } \\
\text { Total }\end{array}$ \\
\hline Comparisons with other campus units & 17 & 15.3 \\
Comparisons with peer institutions' libraries & 12 & 10.8 \\
Setting and meeting goals & 6 & 5.4 \\
Comparisons with census data & 4 & 3.6 \\
No program & 74 & 66.7 \\
\hline
\end{tabular}

librarians, or obtaining feedback from minority librarians when they leave the institution. None of the respondents indicated the use of any other retention efforts related to minority librarians.

The respondents also were asked about methods they might use to measure and evaluate the extent of minority representation on the staff of librarians. Less than one-third undertake such comparisons, with the largest percentage $(15.3 \%$ of total respondents) comparing the library with other campus units in terms of minority employment. Slightly more than ten percent make comparisons with peer libraries, and less than four percent compare library statistics with census data. Finally, 5.4 percent evaluate success on the basis of setting and meeting goals related to representation.

\section{Diversity Awareness}

Efforts to increase awareness of diversity issues have been undertaken in slightly more than half of the libraries (table 5). Such efforts include diversity or sensitivity training workshops in slightly more than a third of the libraries that have implemented awareness programs and the availability of staff funding to participate in professional development or other educational opportunities related to diversity in just over one-quarter of the libraries. However, only seven percent of those who have undertaken such programs have conducted diversity climate surveys in the library. Moreover, less than four percent have hired outside consultants to advise the library on issues of diversity. Other activities have included participation in college-run diversity awareness and training or cultural sensitivity workshops and staff discussions of issues of diversity, among others.

Generally, a very small percentage of the libraries have a library diversity committee $(4.5 \%)$ or a library diversity or affirmative action officer (3.6\%). In contrast,

\begin{tabular}{|lcc|}
\hline \multicolumn{3}{c|}{ TABLE 5 } \\
Effort to Increase Awareness of Diversity \\
\hline \hline Activity & $\begin{array}{c}\text { No. of } \\
\text { Libraries }\end{array}$ & $\begin{array}{c}\text { \% of } \\
\text { Total }\end{array}$ \\
\hline Diversity/sensitivity training workshops & & \\
(in library) & 20 & 18.0 \\
Professional development funding & 16 & 14.4 \\
Diversity/sensitivity training workshops & & 12.6 \\
(on campus) & 14 & 8.1 \\
Campus discussions/staff discussions & 9 & 3.6 \\
Diversity climate surveys in library & 4 & 1.8 \\
Hiring outside consultants to advise & 2 & \\
\hline
\end{tabular}




\begin{tabular}{|lcr|}
\hline \multicolumn{3}{c|}{ TABLE 6 } \\
\\
\hline \hline Committee or Position & $\begin{array}{c}\text { No. of } \\
\text { Libraries }\end{array}$ & $\begin{array}{c}\text { \% of } \\
\text { Total }\end{array}$ \\
\hline Library diversity committee & 5 & 4.5 \\
Library diversity/affirmative action officer & 4 & 3.6 \\
College diversity/affirmative action officer & 80 & 72.1 \\
\hline
\end{tabular}

as might seem more appropriate based on the size of the libraries and colleges, a much larger percentage $(72.1 \%)$ reported having a college diversity or affirmative action officer (table 6).

\section{Services to Specific Segments of the Student Population}

It should be noted that with regard to library and information services, more than half the respondents indicated that their libraries offer and provide services to particular segments of the student population. Specifically, 36 percent of the total provide services to minority students, as shown in table 7 . That is, of the libraries that provide services to specific segments of the student population, nearly two-thirds $(64.5 \%)$ provide them to minority students. A larger percentage of the total (38.7\%) provide services to international students, compared to only 23.4 percent that provide them specifically to students with disabilities. "Other" student populations to which services are provided include gay and lesbian students (3.6\% of the total) and firstgeneration college students $(0.9 \%)$.

The types of services provided, as identified by the respondents, include reference assistance (32.4\%), computer/information technology assistance (28.8\%), tu- toring services $(6.3 \%)$, and orientation programs (14.4\%).

\section{Library Collections}

More than three-quarters of the respondents' libraries have undertaken assessment of the library collections with regard to resources for or about diverse populations (table 8). In addition, nearly twothirds $(63.1 \%)$ have undertaken activities to diversify their collections. In fact, more than half the libraries $(57.7 \%)$ have secured funding to diversify their collections. As shown in table 9, steps taken to do so have included the redirection of funding within the library budget $(40.5 \%)$, the acquisition of new or addi-

The presence of a college diversity/ affirmative action officer was shown to correlate with significant differences in terms of a number of diversity-related activities, in the areas of professional recruitment and services to segments of a diverse student population.

tional funding from the college (15.3\%), and/or the procurement of grants, endowments, and donations to diversify the collections $(23.4 \%)$.

\section{TABLE 7}

Services to Segments of a Diverse Student Population

\begin{tabular}{lcc}
\hline \hline Groups Targeted & $\begin{array}{c}\text { No. of } \\
\text { Libraries }\end{array}$ & $\begin{array}{c}\text { \% of } \\
\text { Total }\end{array}$ \\
\hline International students & 43 & 38.7 \\
Minority students & 40 & 36.0 \\
Students with disabilities & 26 & 23.4 \\
Others & 5 & 4.5 \\
\hline
\end{tabular}




\begin{tabular}{|lcc|}
\hline \multicolumn{3}{c|}{ TABLE 8 } \\
\hline \multicolumn{3}{|c|}{ Diversification of Library Collections } \\
\hline \multirow{2}{*}{ Activities } & $\begin{array}{c}\text { No. of } \\
\text { Libraries }\end{array}$ & $\begin{array}{c}\text { \% of } \\
\text { Total }\end{array}$ \\
\hline Collection assessment & 84 & 75.7 \\
Programs to diversify collection & 70 & 63.1 \\
Funding secured to diversify collection & 64 & 57.7 \\
\hline
\end{tabular}

\section{Overall Evaluation}

To determine the level of impact that managerial activities and administrative structure have had on awareness, staffing, collections, and services, chi-squares were calculated for a number of items. Specifically, the existence of a diversity committee or diversity/affirmative action officer in the library was considered with regard to the level of difference in terms of the extent to which diversity-related activities have been undertaken. The presence of a college diversity/affirmative action officer was evaluated in a similar fashion. The results indicate that there is no statistically significant relationship between the existence of one of these officers or committees and another. In other words, the presence of one generally does not seem to correlate with the presence of another in an institution or library. It is interesting to note that there are no instances in which an organization has both a library diversity committee and a library diversity/affirmative action officer. However, although eighty $(72 \%)$ of the colleges have diversity/affirmative action officers, in the four cases in which a library has a diversity/affirmative action officer, there also is a college diversity/affirmative action officer.
The presence of a college diversity/ affirmative action officer was shown to correlate with significant differences in terms of a number of diversity-related activities, in the areas of professional recruitment and services to segments of a diverse student population. First, the fact that there is a college administrator with responsibility in this area correlates with significant differences in terms of efforts to attract a diverse pool of candidates for open positions. With a chi-square of 0.025 , the analysis of data indicates that in the seventy-eight institutions with a college diversity/affirmative action officer, the directors of seventy-two of their libraries (92.31\% of the total) report recruitment efforts designed to increase the diversity in the applicant pool for professional positions. In contrast, only 76.67 percent of the libraries without a college diversity officer have undertaken such recruitment efforts (table 10). Similar differences were not noted, however, in relation to support staff or student employee positions. In addition, the institutions with college diversity officers reported that library search/selection positions are trained in diversity issues more often than is the case in institutions that do not have a college officer with those responsibilities. Al-

TABLE 9

Sources of Funding for Diversification of Library Collections

\begin{tabular}{lcc} 
Funding Source & $\begin{array}{c}\text { No. of } \\
\text { Libraries }\end{array}$ & $\begin{array}{c}\text { \% of Libraries } \\
\text { That Have Secured } \\
\text { Funding }\end{array}$ \\
\hline Redirection of funding within library budget & 45 & 40.5 \\
New/additional funding from the college & 17 & 15.3 \\
New/additional funding from other source(s) & 26 & 23.4
\end{tabular}


TABLE 10

Differences in Activity Reported, Based on the Presence of College Diversity Officers

\begin{tabular}{lccc}
\hline \hline Activity & $\begin{array}{c}\text { College } \\
\text { Diversity } \\
\text { Officer }\end{array}$ & $\begin{array}{c}\text { No College } \\
\text { Diversity } \\
\text { Officer }\end{array}$ & Chi-square \\
\hline $\begin{array}{l}\text { Efforts to attract a diverse pool } \\
\text { of applicants for professional positions }\end{array}$ & $92.31 \%$ & $76.67 \%$ & 0.025 \\
$\begin{array}{l}\text { Search committees trained in issues } \\
\text { of diversity }\end{array}$ & $51.25 \%$ & $26.70 \%$ & 0.021 \\
$\begin{array}{l}\text { Compilation of staff composition statistics } \\
\text { Services to segments of diverse } \\
\text { student population }\end{array}$ & $48.75 \%$ & $30.00 \%$ & 0.077 \\
\hline
\end{tabular}

though slightly more than half the libraries that are part of institutions with college diversity/affirmative action officers provide training for search committees on issues of diversity, only 26 percent of the libraries without a college diversity officer provide such training, as represented by a chi-square of 0.021 . In the area of maintaining statistics related to library staff composition, differences also were noted. The library directors of slightly less than half the institutions with college diversity officers reported that such statistics on staff composition are compiled, compared to less than 33 percent of the institutions without such a college administrative officer. As represented by a chi-square of 0.077 , the level of difference is approaching significance. Finally, the number of libraries that have implemented programs designed to provide services to segments of a diverse student population differ significantly on the basis of the presence of a college diversity officer. Whereas 61 percent of those libraries within institutions with college diversity officers offer services to specific segments of the student population, only 40 percent of those within institutions without a college diversity officer have implemented such programs, as represented by a statistically significant chi-square of 0.046 .

Having a library diversity committee has not led to a significant difference in any of the other categories of activity related to diversity. The fact that the library has a diversity/affirmative action officer is correlated with a significant difference in the extent to which statistics related to library staff composition are compiled. With a chi-square of 0.020 , it is noted that whereas only slightly more than 40 percent of the libraries without a library diversity officer compile such data, all of the institutions that have a library diversity/affirmative officer do compile them. However, it is important to consider that only four of the institutions have such a position in the organization. Moreover, the fact that there is a library diversity/ affirmative action officer does not correlate to a statistically significant degree with other, related activities, such as efforts to increase the awareness of diversity issues among library staff, attract a diverse pool of applicants for open positions, train library search committees in diversity issues, offer target-of-opportunity programs, or implement library programs designed to provide services to segments of a diverse student population.

\section{Summary}

A number of conclusions should be noted on the basis of the results and analysis of data in this study. Generally, the level of activities related to diversity among liberal arts college libraries is not overwhelming, in any categories of activity.

Certainly, the presence of an officer of the college who has responsibility for issues of diversity and affirmative action, 
which might be read as institutional support for such issues, does appear to lead to a greater level of activity related to diversity in a number of areas. However, it does appear that this is not the case for all categories of activity, particularly those beyond the important areas of recruitment and staffing. The participants in the study were asked about the college and library diversity/affirmative action officers and library diversity committees that were a part of their institutions and about the programs, activities, and services they have implemented. It does not seem that the presence of a library diversity/affirmative action officer or committee has been correlated with a statistically significant level of difference in the activity related to awareness, staffing, services, or collections. However, the directors were not asked, specifically, about the role of the college diversity officer in rewarding, encouraging, or requiring these activities. Thus, the results and the analysis have been reported on the basis of the presence of these committees and officers, the activities undertaken and reported, and the levels of significance in terms of difference in the presence and level of activity. The specific activities of these officers and committees were only addressed on the basis of specific survey items, such as the provision of training for search committees and the compilation of statistics related to staff composition. Further study is needed with regard to other roles of these officers and committees in relation to goal setting, accountability, incentives, the provision of other types of guidance and assistance, and their representation of an institutional and administrative commitment to issues of diversity.

With regard to the issue of professional recruitment, more than one-third of the libraries employ no minority librarians at present and more than half have not un- dertaken efforts to retain minority librarians. It is clear that when the role of the college diversity/affirmative action officer is considered (as well as the role of minority faculty and staff members who participate in the widely used approach related to the retention of minority librarians), the presence and use of resources outside the library appear to be important to organizational efforts related to diversity. This reliance on external resources may be necessary due to the fact that internal resources may be limited. The rate of return for this study may indicate that a very small number of respondents did not complete the questionnaire because they were concerned that their institutions' size and limited resources make it difficult to undertake some of the activities suggested in the survey instrument. ${ }^{18}$

Although more than half the libraries have undertaken efforts to increase awareness of issues of diversity, only seven percent have employed climate surveys. Thus, further research related to organizational culture is likely to be important for those libraries that have attempted to increase awareness as well as for those that have not.

In conclusion, continuing exploration of issues related to diversity is needed as a part of the focus on issues of representation and the development and provision of information services and access to collections. The goals related to diversity and equity are far more likely to be achieved when the issues are well defined and when we have a clearer understanding of the extent of underrepresentation and the factors that are likely to enhance our efforts. As this study addresses the issue of diversity in liberal arts college libraries, the issues with regard to an important segment of the academic library community are being better defined and their goals more likely to be realized.

\section{Notes}

1. Julie Brewer, "Post-Master's Residency Programs: Enhancing the Development of New Professionals and Minority Recruitment in Academic and Research Libraries," College E Research Libraries 58 (Nov. 1997): 528. 
2. Ibid., 535 .

3. Mark Winston and Karen Downing, "Helping Students of Color Succeed: Implementing and Managing a Peer Information Counseling Program," Leading Ideas 3 (July 1998): 4.

4. Climate Survey at the Pennsylvania State University Libraries, Dec. 1998 [Online]. Available from http://www.libraries.psu.edu/divers/conf/climate.htm.

5. Brewer, "Post-Master's Residency Programs," 537.

6. The Ohio State University, Statistical Summary, Dec. 1999 [The Ohio State University home page]. Available from http://www.osu.edu/units/ucomm/stuinfo.html\#enroll.

7. The University of Michigan Library, "Point of Intersection: The University Library and the Pluralistic Campus Community," Information Reports \& Bibliographies 19, no.3 (1990).

8. Haipeng Li, "Diversity in the Library: What Could Happen at the Institutional Level," Journal of Library Administration 27 (1999): 146.

9. Terrence Mech, "Small College Library Directors of the Midwest," Journal of Academic Librarianship 11 (Mar. 1985): 8.

10. Robert D. Stueart, "The Liberal Arts College Library: Paradox or Panacea," College $\mathcal{E}$ Research Library News 51 (Nov. 1990): 529.

11. Mech, "Small College Library Directors of the Midwest," 13.

12. Joseph R. Diaz, Jennalyn Tellman, and DeEtta Jones, Affirmative Action in ARL Libraries, ARL Spec Kit \#230 (Washington, D.C.: ARL Office of Leadership and Management Services, June 1998).

13. Ibid., 1.

14. Ibid., 7.

15. Ibid., $1-2$.

16. Ibid., 2.

17. The Carnegie Foundation for the Advancement of Teaching, Dec. 1998 [Online].

18. In some instances, the respondents completed the survey instrument and provided comments in addition to the survey responses. In addition, a number of respondents made reference to issues of fairness, etc., which are considered to be a part of all of their hiring processes and other activities. 